\author{
M. MozhaIEV, N. KuChuK, M. UsATENKO
}

\title{
THE METHOD OF JITTER DETERMINING IN THE TELECOMMUNICATION NETWORK OF A COMPUTER SYSTEM ON A SPECIAL SOFTWARE PLATFORM
}

Relevance of the study: When choosing a platform, the quality criteria for computer system service depend significantly on the parameters of the basic telecommunications network. Therefore, the telecommunications network has strict requirements. In addition, the network must satisfy a number of constraints that are set by the computer system. Only the fulfillment of these conditions will allow the computer system to solve its tasks. Also, when constructing, modifying and operating telecommunication networks, there is a rather common problem with no digital signal processing, network synchronization and stability. The tasks of ensuring temporary requirements for system transactions: it is necessary to find the most significant QoS parameters that allow dynamic network reconfiguration to ensure the fulfillment of temporary requirements for system transactions. Subject of study: jitter of the telecommunication network. The purpose of the article is to develop a method of prompt calculation of jitter values of a telecommunication network for dynamic adjustment of network parameter. Results of the study: The analysis of the influence of nonstationarity of data transmission in the telecommunication subsystem of the investigated computer system was carried out. The classification of jitter and causes leading to its occurrence has been made. The results of the analysis of the factors that improve the quality of data transmission in the network due to the operational jitter frequency calculation are presented. Researches of the resolution characteristics of coherent acousto-optic spectro-analysers are carried out in the work. Analytical ratios for the output signal were obtained for two monochromatic radio signals at the input, taking into account the effects of nonlinear interaction of the output signals and the a priori dependence of the location and width of the diffraction spot on the frequency of the investigated signal. The most significant qualitative and quantitative characteristics of frequency separation are shown in the example of two monochromatic signals, which differ only in carrier frequencies. These analytical ratios were experimentally verified by simulation of the system. Conclusions. As a result of the research, a method of increasing the resolution of acousto-optic spectro analyzers was proposed due to the features of coherent signal interaction in the frequency jitter computation process. It is based on the method of operative calculation of jitter value of telecommunication network, which allows performing dynamic adjustment of network parameters.

Keywords: computer system; telecommunication network; jitter.

\section{Introduction}

Computer systems find applications in diverse spheres of human society: industry, business, science and education, finance and infrastructure projects, construction and law enforcement. Depending on the purpose of the system, the appropriate software platform is selected for its construction. Such a platform defines the behavior of the underlying telecommunications network. In particular, such platforms are currently popular: cloud, converged, hyper-converged. When choosing a platform, the quality criteria for computer system service depend significantly on the parameters of the underlying telecommunications network. Therefore, stringent requirements are set before the formed telecommunication network. In addition, the network must meet a number of limitations that are imposed by the computer system. Only the fulfillment of these conditions will allow the computer system to solve its tasks. Also, the construction, modification and operation of telecommunications networks raise a fairly common problem with digital signal processing, network synchronization and its stability.

\section{Problem statement}

In the course of functioning of the computer system on the special software platform the task is set to fulfill the temporary requirements for system transactions. This task becomes most significant when choosing centralized control platforms (converged and hyper converged) [1, 2]. The query execution time depends on both the quality of service (QoS) parameters of the underlying telecommunications network and the architecture of the computer system. However, in systems with centralized control, the effect of architecture is much smaller. Thus, the task of securing system transaction temporary requirements can be formulated as follows: it is necessary to find the most essential QoS parameters that allow for dynamic network reconfiguration to ensure compliance with system transaction temporary requirements.

\section{Literature analysis}

An analysis of the influence of telecommunication network parameters on the quality of service (QoS) has been the subject of many scientific papers [3-21]. So, in [3-6] the influence of channel capacity was studied. In $[7,8]$, the influence of network architecture is analyzed. In $[4,5]$, the main emphasis is placed on the architecture of a computer system. In [9-12], packet queues were analyzed. A complex approach for QoS analysis was proposed in $[13,14]$. In addition, there is a separate question about the relationship of QoS indicators and the fulfillment of the requirements for transactions of a computer system [15-20]. In [21], the basic parameters of the basic telecommunication network that affect the quality of transaction execution of a computer system are identified. In particular, it has been shown that when choosing special platforms with centralized control (convergent and hyper converged), the importance of jitter plays an important role. Jitter is the least researched parameter in telecommunication networks. The quality of dynamic reconfiguration of telecommunication network 
parameters, in particular, is determined by the accuracy of determining the jitter value.

\section{Purpose of the article}

The aim of the article is to develop a method for the operational calculation of the jitter of a telecommunication network for dynamic reconfiguration of network parameters.

\section{Jitter - Signal Approach}

The object of study is jitter (phase jitter), the phenomenon of phase modulation of the received signal (both analog and digital). Currently, two approaches to determining jitter are most widely used - in terms of phase and in terms of frequency. It is known that the frequency and phase parameters are connected by a simple relation, i.e. both approaches are equivalent. The description of jitter as the phase instability of the received digital signal is most often used in theoretical studies. This led to the emergence of definitions of jitter as phase fluctuations. But in practice, there are objective difficulties in measuring the phase. Therefore, an applied representation of jitter appeared as a variation in the frequency of the received signal. In this representation, the amplitude and frequency of the received signal become the main parameters of the jitter.

Recently, much attention has been paid to the use of optical methods in the analysis of data of various natures [22-24], which is due to the specific capabilities of such methods: parallel processing, high speed and frequency of optical signals, etc.

These capabilities are realized, for example, in modern acoustic-optical spectrum analyzers, which are distinguished by the simplicity of design and parallel processing of signals in a wide frequency band and in almost real time [22]. Using the advantages of non-search spectral analysis and expanding the band of simultaneously analyzed frequencies in acoustic-optical spectrum analyzers necessitates a deeper analysis of their resolution.

In most studies on the resolution of acousto-optic spectrum analyzers, these studies are carried out using the Rayleigh criterion [22, 23]. This happened historically, by analogy with the resolution of most optical instruments, for example, telescopes. But unlike the study of natural sources of radiation, for example, stars whose radiation is incoherent, in acoustic-optical spectrum analyzers, coherent laser radiation is used. Estimates of the resolution, carried out by the Rayleigh criterion [23], show that when a signal $\Delta f / f \approx 0,01$ is detuned, the pulses are no longer distinguishable, regardless of the signal delay time.

Thus, the resolution of acoustic-optical spectrum analyzers, based on the application of the Rayleigh criterion, is much less than the potential resolution of the measuring system, which, as is known from the general theory of radar, is determined by the pulse width $\Delta f=1 / \tau_{u}$ or the diffraction grating parameters of the spectrum analyzer.
2. Analysis of the causes of jitter and methods for its measurement

Measuring jitter parameters is becoming increasingly important throughout the life cycle of digital systems. Currently, the development and implementation of new standards for fast data transfer (such as InfiniBand, PCI Express, 10-Gigabit Ethernet, etc.) is underway with data transfer rates exceeding and significantly $1 \mathrm{~Gb} / \mathrm{s}$. At these speeds, given the analog nature of the signal, to ensure the reliability of the signal, it is necessary to allocate a significant part of the computing resource. Obtaining a trustworthy result is possible when performing rather complicated procedures for setting up the corresponding elements of a telecommunication network

For more accurate jitter measurements, it is necessary to analyze the nature of the occurrence of this effect and its classification.

Most often, jitter is caused by amplitude and phase noise, both internal and external origin.

Usually, jitter is divided into two main classes: random (random jitter - RJ) and regular (deterministic jitter - DJ). Random jitter is caused by stochastic noise processes that exist in the entire elemental base and components of a telecommunication system. For a random jitter, the Gaussian distribution is believed to be valid. Therefore, such a jitter is characterized by well-known statistical values: average value and standard deviation. Random jitter is a consequence of such physical processes as: - thermal noise (thermal noise) - is caused by the flow of electrons in the conductors and increases with increasing bandwidth, temperature and thermal resistance; - shot noise (shot noise) - the noise of electrons and holes in semiconductors, which increases depending on the bias current and the measured frequency band; - flicker noise noise whose spectrum is inversely proportional to frequency, the so-called pink noise.

Regular jitter is caused by the influence on the signal of the processes occurring in the equipment of a telecommunication system, and it can also appear depending on the methods of representing the transmitted data. System jitter depends on the characteristics of the digital system.

Examples of system jitter sources:

- crosstalk from emitted or transmitted signals;

- the effect of dispersion during signal propagation;

- mismatch of resistances.

The dependence of the appearance of jitter on the method of presenting data is most significant when the coding scheme or other characteristics of the transmitted data cause network jitter, which appears on the receiver side. Sources of data-dependent jitter are:

- intersymbol interference;

- distortion of the duty cycle of the pulse sequence;

- periodicity of a pseudo-random binary sequence.

The study of jitter in the frequency domain allows us to determine the main causes that caused it. Sources of deterministic jitter can be determined by analyzing the line (discrete) spectrum of the received signal. When analyzing the frequency spectrum, phase noise or jitter spectrum studies are carried out. In this case, the jitter is related to the frequency shift of the received signal 
relative to its carrier frequency. Studies of phase noise make it possible to provide the most accurate jitter estimate due to the significantly higher signal sampling frequency and the ability to control the frequency band. It is easy to determine the deterministic jitter by the peaks in the spectrum using crystal oscillators with phase-locked loop.

Another method for studying frequency jitter is to use the fast Fourier transform (FFT). The FFT method is not as accurate as to measure weak phase noise, but it is not replaceable if you need to quickly and easily view significant processes.

In general, differentiation of jitter into components is not a way to determine it, but it is important in the practical field - both for finding the causes of malfunctions and for assessing the reliability of development. If it is possible to isolate deterministic jitter, and then to calculate the trend of the standard deviation of random jitter, then it will be possible to estimate the bit error rate (BER) and determine the boundaries of the system's performance without using the lengthy measurements that are required to determine the BER with an accuracy of about $10-12$ at $95 \%$ certainty.

The easiest way is to evaluate the jitter according to the eye diagram. An eye diagram is a summary view of all bit periods of a measured signal superimposed on one another. Fig. 1 shows a histogram of the transition region of the eye diagram.

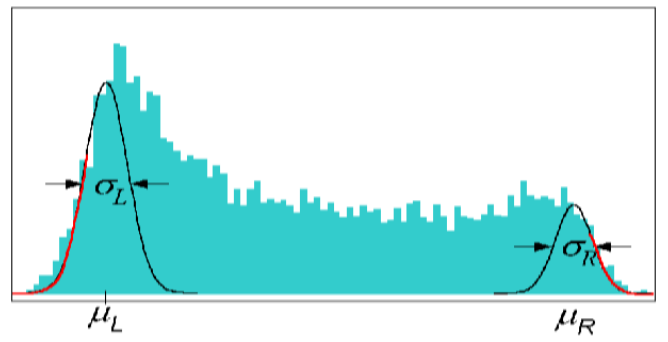

Fig. 1. Histogram of the transition region of the eye diagram

$$
E_{1}\left(x_{1}, t\right)=A r\left(x_{1}\right) \cdot s\left(t-\frac{x_{1}+D / 2}{v}\right) \exp \left[i\left(\omega_{L} t-k_{L} z_{1}+k_{L} x_{1} \operatorname{tg} \theta\right)\right],
$$

where $A$ characterizes the modulating effect of an acoustic wave on laser radiation passing through an acoustic-optical modulator.

In the output plane of the acoustic-optical spectrum analyzer, the field will be written as

$$
E_{2}\left(x_{2}, t\right)=\int d x_{1} E_{1}\left(x_{1}, t\right) \exp \left(i \frac{2 \pi}{\lambda F} x_{1} x_{2}\right) .
$$

Using expression (1), formula (2) can be transformed to

$$
E_{2}\left(x_{2}, t\right)=A v \exp \left(-i \omega_{x} T / 2\right) \int_{0}^{T} d \tau \exp \left(i \omega_{x} \tau\right) \cdot s(t-\tau)
$$

where the negligible factor $\exp \left[i\left(\omega_{L} t-k_{L} z_{1}\right)\right]$ is omitted and the designation $\omega_{x}=v\left(\frac{2 \pi}{\lambda F} x_{2}+k_{L} \operatorname{tg} \theta_{i}\right) \quad$ is
Along the edges of the diagram, random jitter has the greatest impact, while deterministic jitter components dominate in the center. To determine the parameters of random jitter along the edges of the histogram, you need to "enter" the graphs of the Gauss function and calculate the statistical characteristics of the random process (mathematical expectation and variance) from them.

Thus, the quality of determining jitter in the frequency representation requires improving the accuracy of measuring the frequency of the received signal, which, in turn, necessitates increasing the resolution of modern spectrum analyzers. At present, acousto-optic spectrum analyzers are widely used, which make it possible to determine the spectrum of the signal under investigation with high speed. At the same time, for measuring jitter, as noted above, the high resolution capability of this device is important. Further research will be devoted to assessing the resolution of acousto-optic spectrum analyzers taking into account coherent interaction.

\section{Basic relationships and formulations}

The structural diagram of the spectrum analyzer, together with the main analytical relationships characterizing the processes occurring in acoustic-optical spectrum analyzers, are quite fully described in [22]. We use these data to formulate the problem of studying the interaction of two monochromatic radio signals of close frequency and determining the limiting values of the resolution of acousto-optic spectrum analyzers.

We assume that the input of the analyzer receives a radio signal $s(t)$, which is converted into a traveling acoustic wave $r\left(x_{1}\right) \cdot s\left(t-\frac{x_{1}+D / 2}{v}\right)$ propagating with a speed $v$. In the linear approximation, the field of the light wave of the first diffraction order is represented as introduced, and $T=\frac{D}{v}$ - the duration of the time sample corresponding to the time aperture $D$. In the formula (3) and everywhere below, the dependence of the field $E_{2}$ on $x_{2}$ by $\omega_{x}=\omega\left(x_{2}\right)$ is clearly reflected.

\section{Resolution of two monochromatic radio signals}

Let two monochromatic radio signals of unit amplitude, but with different carrier frequencies, simultaneously arrive at the input of a nonlinear analyzer $\omega_{a}(a=1,2)$ :

$$
S(t)=S_{1}(t)+S_{2}(t)
$$

where

$$
S_{a}(t)=\sin \left(\omega_{a} t+\phi_{a}\right) .
$$

Substituting (4) into (3) gives: 


$$
E_{2}\left(\omega_{x}, t\right)=E^{(1)}\left(\omega_{x}, t\right)+E^{(2)}\left(\omega_{x}, t\right),
$$

where the term $E^{(a)}\left(\omega_{x}, t\right)$ is the corresponding response to the $a$-th input radio signal $(a=1,2)$.

Thus, taking into account the nonlinearity of the elements of the recording device, and also by virtue of (5), the total recorded signal can be written in the form

$$
U\left(\omega_{x}, t\right)=U_{1}\left(\omega_{x}, t\right)+U_{2}\left(\omega_{x}, t\right)+U_{1,2}\left(\omega_{x}, t\right),
$$

where

$$
U_{a}\left(\omega_{x}, t\right)=\left|E_{2}^{a}\left(\omega_{x}, t\right)\right|^{2}
$$

represents the input signal if there is only the $a$-th signal at the input, and the third term

$$
U_{1,2}\left(\omega_{x}, t\right)=E^{(1)}\left(\omega_{x}, t\right) * \overline{E^{(2)}\left(\omega_{x}, t\right)}
$$

arises as a result of interference of the first two (a bar above means complex conjugation). Unlike [23], we did not integrate over time the amplitudes of the received signal. Thus, the features of the acoustic-optical spectrum analyzer as a device in which the coherent signals interact are taken into account

\section{Numerical calculations and discussion of the results}

The most significant qualitative and quantitative characteristics of frequency resolution can be seen already on the example of two monochromatic signals that differ only in carrier frequencies.

Fig. 2 illustrates the results of the calculation of the output signal using formulas (7), (8) for a significant frequency mismatch of monochromatic radio signals. Obviously, in this case it is possible to resolve the radio signals using the traditional method (for example, [2224]). The authors are more interested in the magnitude of the diffraction spot $\Delta \omega_{x 1,2}$. Due to the specific conditions of propagation of radio signals in an acoustic-optical spectrum analyzer, each input signal at a certain frequency corresponds not only to its value $\Delta \omega_{x 1,2}$, but also to its own width of the diffraction spot $\Delta \omega_{x}$. This can be verified by calibrating an acoustic-optical spectrum analyzer. Thus, it is possible to significantly increase the resolution of the acousto-optic spectrum analyzer, since each independent frequency of the input signal corresponds to two independent parameters.

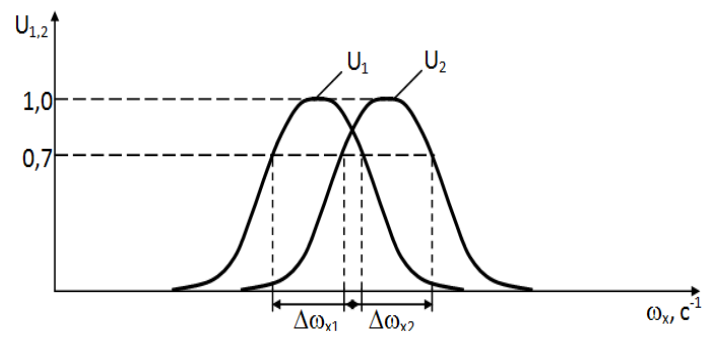

Fig. 2. The output signal with a large value of the detuning of the carrier frequency
Fig. 3 presents the results of calculations of the output signal with a small value of the frequency detuning of the input radio signals.

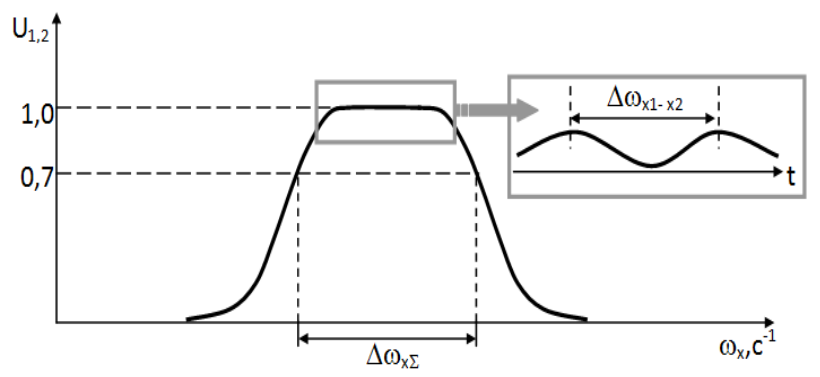

Fig. 3. The output signal with a small value of the mismatch of the carrier frequency

The main difference between these calculations and those performed in [24] is that in the common part of two radio signals at different frequencies, fluctuations in the amplitude of the output signal with frequencies much lower than the carrier frequencies of the monochromatic radio signals under study can be detected. Calculations (7), (8) were performed without integration over time, which made it possible to detect, determine and identify beats, i.e. oscillations at combination frequencies, which is impossible under the assumptions on which previous studies were based. Then, by measuring and analyzing the values $\Delta \omega_{x \Sigma}$ and frequencies of the beats $\Delta \omega_{x 1-x 2}$, it is possible to significantly increase the frequency resolution of the acoustic-optical spectrum analyzer.

For this, it is necessary, firstly, from time to time to calibrate the acousto-optic spectrum analyzer as $\Delta \omega_{x}=f(s(t))$, that is, as a function of the input signal, as well as to allocate the maximum value of the carrier frequency detuning (beats). This algorithm can make it possible to approximate the limiting values of the frequency resolution of radio signals by acoustic-optical spectrum analyzers to the predicted by the general theory of radar.

As a result of the studies conducted in this work, a method was proposed for increasing the resolution of coherent acousto-optic spectrum analyzers due to the peculiarities of coherent signal interaction. Using a method for increasing the resolution of acousto-optic spectrum analyzers due to the peculiarities of coherent interaction of signals in calculating jitter will significantly increase control over the quality of signal transmission over data transmission channels of a telecommunication network, which will undoubtedly provide the prerequisites for improving the quality indicators of the entire computer system. The proposed method for the operational calculation of the jitter value of a telecommunication network will allow for dynamic reconfiguration of network parameters.

\section{Conclusions}

The article analyzes the influence of non-stationary data transmission in the telecommunication subsystem of the investigated automated system. The role of jitter on 
the quality of information transfer in a telecommunication network is investigated. The classification of jitter and the reasons leading to its occurrence are carried out. The results of the analysis of factors improving the quality of data transmission in the network due to the on-line calculation of frequency jitter are presented. The paper studies the resolution features of coherent acousto-optic spectrum analyzers. Analytical relations are obtained for the output signal with two monochromatic radio signals at the input, taking into account the effects of nonlinear interaction of the output signals and the a priori dependence of the location and width of the diffraction spot on the frequency of the signal under study. The given analytical relationships were experimentally verified by simulation of the system. The simulation results confirmed their agreement with the previously obtained theoretical ones. As a result of research, a method was proposed for increasing the resolution of acoustic-optical spectrum analyzers due to the peculiarities of coherent interaction of signals in the process of calculating frequency jitter. On its basis, a method has been developed for the operational calculation of the jitter of a telecommunication network, which allows dynamic reconfiguration of network parameters.

It is advisable to devote further research to studying methods for increasing the resolution of acousto-optic spectrum analyzers to the theoretically maximum possible limits using optimal signal processing methods. This will improve the quality of dynamic reconfiguration of network parameter.

\section{References}

1. Merlac, V., Smatkov, S., Kuchuk, N., Nechausov, A. (2018), "Resourses Distribution Method of University e-learning on the Hypercovergent platform", Conf. Proc. of 2018 IEEE 9th International Conference on Dependable Systems, Service and

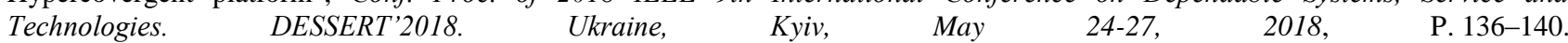
DOI: http://dx.doi.org/10.1109/DESSERT.2018.8409114

2. Kuchuk, N., Artiukh, R. and Nechausov, A. (2017), "Method of building the semantic network of distributed search in elearning", Innovative Technologies and Scientific Solutions for Industries, No. 2 (2), P. 62-69. DOI: https://doi.org/10.30837/25229818.2017.2.062

3. Whitt, W. (1983), "The Queuing Network Analyzes", Bell System Tech. I., Vol. 62, No. 9, P. 2779-2815.

4. Kuchuk, G. A. (2007), "Traffic management of multiservice distributed telecommunication network" ["Upravlinnya trafikom mul'tyservisnoyi rozpodilenoyi telekomunikatsiynoyi merezhi"], Management, navigation and communication systems, Kyiv : TsNII NiU, Issue 2, P. 18-27.

5. Svyrydov, A., Kovalenko, A., Kuchuk, H. (2018), "The pass-through capacity redevelopment method of net critical section based on improvement on/off models of traffic", Advanced Information Systems, Vol. 2, No. 2, P. 139-144. DOI: https://doi.org/10.20998/2522-9052.2018.2.24

6. Kuchuk, G. A., Kovalenko, A. A., Lukov-Chuiko, N. V. (2017), "A method for minimizing the average packet delay in virtual cloud support network connections" ["Metod minimizatsiyi seredn'oyi zatrymky paketiv u virtual'nykh z"yednannyakh merezhi pidtrymky khmarnoho servisu"], Management, navigation and communication systems, No. 2 (42), P. 117-120.

7. Kuchuk, G. A., Ruban, I. V., Davikoza, O. P. (2013), "Conceptual approach to synthesis of information and telecommunication network structure" ["Kontseptual'nyy pidkhid do syntezu struktury informatsiyno-telekomunikatsiynoyi merezhi "], Systems of information processing: collection of scientific works, No. 7 (114), P. 106-112.

8. Lemeshko, O., Yevdokymenko, M., Yeremenko, O. (2019), "Model of data traffic QoS fast rerouting in infocommunication networks", Innovative Technologies and Scientific Solutions for Industries, No. 3 (9), P. 6-13. DOI: https://doi.org/10.30837/25229818.2019.9.127

9. Kosenko, V. (2017), "Mathematical model of optimal distribution of applied problems of safety-critical systems over the nodes of the information and telecommunication network", Advanced Information Systems, Vol. 1, No.2, P.4-9. DOI: https://doi.org/10.20998/2522-9052.2017.2.01

10. Kovalenko, A., Kuchuk, H. (2018), "Methods for synthesis of informational and technical structures of critical application object's control system", Advanced Information Systems, Vol. 2, No. 1, P. 22-27. DOI: https://doi.org/10.20998/2522-9052.2018.1.04 11. Zykov, I., Kuchuk, N., Shmatkov, S. (2018), "Architecture synthesis of the computer system of transaction control e-learning", Advanced Information Systems, Vol. 2, No. 3, P. 60-66. DOI: https://doi.org/10.20998/2522-9052.2018.3.10

12. Gelenbe, E., Pujolle, G. (2010), Analysis and synthesis of computer systems (2nd Edition), Advances in Computer Science and Engineering : Texts, Vol. 4, 309 p.

13. Kuchuk, N., Mohammed, A. S., Shyshatskyi, A. and Nalapko, O. (2019), "The method of improving the efficiency of routes selection in networks of connection with the possibility of self-organization", International Journal of Advanced Trends in Computer Science and Engineering, No. 8(1), P. 1-6, DOI: https://doi.org/10.30534/ijatcse/2019/0181.22019.

14. Kuchuk, G., Kharchenko, V., Kovalenko, A., Ruchkov, E. (2016), "Approaches to selection of combinatorial algorithm for optimization in network traffic control of safety-critical systems", East-West Design \& Test Symposium (EWDTS), P. 1-6. DOI: https://doi.org/10.1109/EWDTS.2016.7807655

15. Mozhaev, O., Kuchuk, H., Kuchuk, N., Mozhaev, M., Lohvynenco, M. (2017), "Multiservise network security metric", IEEE Advanced information and communication technologies-2017, Proc. of the 2th Int. Conf. Lviv, 2017, P. 133-136.

16. Kosenko, V. (2017), "Principles and structure of the methodology of risk-adaptive management of parameters of information and telecommunication networks of critical application systems", Innovative Technologies and Scientific Solutions for Industries, No. 1 (1), P. 75-81. DOI: https://doi.org/10.30837/2522-9818.2017.1.046

17. Kuchuk, G. A., Kovalenko, A. A., Mozhaev, A. A. (2010), "An Approach To Development Of Complex Metric For Multiservice Network Security Assessment", Statistical Methods Of Signal and Data Processing (SMSDP - 2010): Proc. Int. Conf., October 1314, 2010.- Kiev: NAU, RED, IEEE Ukraine section joint SP, 2010, P. 158-160.

18. Kliuiev, O., Mozhaiev, M., Uhrovetskyi, O., Mozhaiev, O., Simakova-Yefremian, E. (2019), "Method of forensic research on image for finding touch up on the basis of noise entropy", 2019 3rd International Conference on Advanced Information and Communications Technologies, AICT 2019 - Proceedings. 
19. Gavrylenko, S. (2019), "Synthesis of identification measurements in the computer system of critical purpose", Innovative Technologies and Scientific Solutions for Industries, No. 2 (8), P. 36-43. DOI: https://doi.org/10.30837/2522-9818.2019.8.036

20. Filimonchuk, T., Volk, M., Risukhin, M., Olshanska, T., Kazmina, D. (2019), The modified information technology for the distribution of resource tasks for cloud computing systems, Innovative Technologies and Scientific Solutions for Industries, No. 1 (7), P. 121-129. DOI: https://doi.org/10.30837/2522-9818.2019.7.121

21. Davydovskyi, Y., Reva, O., Artiukh, O., Kosenko, V. (2019), "Simulation of computer network load parameters over a given period of time", Innovative Technologies and Scientific Solutions for Industries, No. $3(9), \quad$ P. 72-80. DOI: https://doi.org/10.30837/2522-9818.2019.9.072

22. Optical processing of radio signals in real time, [Opticheskaya obrabotka radiosignalov v real'nom vremeni], Ed. S.V. Kulakova, Moscow : Radio and communications, 1989, $136 \mathrm{p}$.

23. Akayev, A. A., Mayorov, S. A. (1988), Optical methods of information processing [Opticheskiye metody obrabotki informatsii], Moscow : Higher school, $237 \mathrm{p}$.

24. Kuchuk, G., Kovalenko, A., Komari, I. E., Svyrydov, A., Kharchenko, V. (2019), "Improving big data centers energy efficiency: Traffic based model and method. Studies in Systems, Decision and Control", Springer Nature Switzerland AG, Vol. 171, P. 161-183. DOI: http://doi.org/10.1007/978-3-030-00253-4_8.

Received 20.11.2019

\section{Вiдомості про авторів / Сведения об авторах / About the Authors}

Можаєв Михайло Олександрович - кандидат технічних наук, Харківський науково-дослідний інститут судових експертиз ім. засл. проф. М.С. Бокаріуса, завідувач лабораторії комп'ютерно-технічних, телекомунікаційних досліджень та досліджень відео-, звукозапису, Харків, Україна; email: mikhail.mozhayev@ hniise.gov.ua; ORCID: http://orcid.org/0000-00031566-9260.

Можаев Михаил Александрович - кандидат технических наук, Харьковский научно-исследовательский институт судебных экспертиз им. засл. проф. Н.С. Бокариуса, заведующий лабораторией компьютерно-технических, телекоммуникационных исследований и исследований видео-, звукозаписи, Харьков, Украина.

Mozhaiev Mykhailo - PhD (Engineering Sciences), Kharkiv SRI Examinations named Dist. prof. N.S. Bokarius, Head of Laboratory on Speech and Audio Computer Engineering and Telecommunication.

Кучук Ніна Георгіївна - кандидат педагогічних наук, доцент, Національний технічний університет "Харківський політехнічний інститут", доцент кафедри обчислювальної техніки та програмування, Харків, Україна; email: nina_kuchuk@ukr.net; ORCID: http://orcid.org/0000-0002-0784-1465.

Кучук Нина Георгиевна - кандидат педагогических наук, доцент, Национальный технический университет "Харьковский политехнический институт", доцент кафедры вычислительной техники и программирования, Харьков, Украина.

Kuchuk Nina - PhD (Pedagogy Sciences), Associate Professor, National Technical University "Kharkiv Polytechnic Institute", Associate Professor of the Computer Engineering and Programming Department, Kharkiv, Ukraine; email: nina_kuchuk@ukr.net; ORCID: http://orcid.org/0000-0002-0784-1465.

Усатенко Максим Віталійович - Національний юридичний університет імені Ярослава Мудрого, студент інституту підготовки кадрів для органів юстиції України, Харків, Україна; email: usatenko@ hniise.gov.ua; ORCID: https://orcid.org/00000001-8480-6666.

Усатенко Максим Витальевич - Национальный юридический университет имени Ярослава Мудрого, студент института подготовки кадров для органов юстиции Украины, Харьков, Украина.

Usatenko Maksym - Yaroslav Mudryi National Law University, Student of Institute of Training for Justice Bodies of Ukraine, Kharkiv, Ukraine.

\section{МЕТОД ВИЗНАЧЕННЯ ДЖИТЕРА В ТЕЛЕКОМУНІКАЦІЙНІЙ МЕРЕЖІ КОМП'ЮТЕРНОЇ СИСТЕМИ НА СПЕЦАЛЬНІЙ ПРОГРАМНІЙ ПЛАТФОРМІ}

Актуальність дослідження. При виборі платформи критерії якості обслуговування комп'ютерної системи істотно залежать від параметрів базової телекомунікаційної мережі. Тому перед телекомунікаційною мережею ставлять жорсткі вимоги. Крім того, мережа повинна задовольняти низці обмежень, які поставлені комп'ютерною системою. Тільки виконання цих умов дозволить комп'ютерній системі вирішити поставлені перед нею завдання. Також при побудові, модифікації і експлуатації телекомунікаційних мереж виникає досить загальна проблема щодо цифрової обробки сигналів, синхронізації мережі та їі стабільності. Завдання забезпечення часових вимог до системних транзакцій: необхідно знайти найбільш істотні параметри $\mathrm{QoS}$, що дозволяють проводити динамічне переналагодження мережі для забезпечення виконання часових вимог до системних транзакцій. Предмет дослідження: джитер телекомунікаційної мережі. Метою статті $€$ розробка методу оперативного розрахунку значення джитера телекомунікаційної мережі для проведення динамічного переналагодження мережевих параметрів. Результати дослідження. Проведено аналіз впливу нестаціонарності передачі даних в телекомунікаційній підсистемі досліджуваної комп'ютерної системи. Досліджено роль джитера на якість передачі інформації в телекомунікаційній мережі. Проведено класифікацію джитера і причин, що призводять до його виникнення. Наведено результати аналізу факторів, що поліпшують якість передачі даних в мережі за рахунок оперативного обчислення частотного джитера. В роботі проведені дослідження особливостей роздільної здатності когерентних акустооптичних спектроаналізаторів. Отримано аналітичні співвідношення для вихідного сигналу при двох монохроматичних радіосигналах на вході, що враховують ефекти нелінійної взаємодії вихідних сигналів і апріорну залежність розташування і ширини 
дифракційної плями від частоти досліджуваного сигналу. Найбільш суттєві якісні та кількісні характеристики частотного розділення показані на прикладі двох монохроматичних сигналів, що відрізняються тільки несучими частотами. Наведені аналітичні співвідношення були експериментально перевірені за допомогою імітаційного моделювання системи. Висновки. В результаті досліджень було запропоновано спосіб підвищення роздільної здатності акустооптичних спектроаналізаторів за рахунок особливостей когерентної взаємодії сигналів в процесі обчислення частотного джитера. На його базі розроблено метод оперативного розрахунку значення джитера телекомунікаційної мережі, який дозволяє провести динамічне переналагодження мережевих параметрів.

Ключові слова: комп'ютерна система; телекомунікаційна мережа; джитер.

\section{МЕТОД ОПРЕДЕЛЕНИЯ ДЖИТТЕРА В ТЕЛЕКОММУНИКАЦИОННОЙ СЕТИ КОМПЬЮТЕРНОЙ СИСТЕМЫ НА СПЕЦИАЛЬНОЙ ПРОГРАММНОЙ ПЛАТФОРМЕ}

Актуальность исследования. При выборе платформы критерии качества обслуживания компьютерной системы сушественно зависят от параметров базовой телекоммуникационной сети. Поэтому перед телекоммуникационной сетью ставят жесткие требования. Кроме того, сеть должна удовлетворять ряду ограничений, которые поставлены компьютерной системой. Только выполнение этих условий позволит компьютерной системе решить поставленные перед ней задачи. Также при построении, модификации и эксплуатации телекоммуникационных сетей возникает достаточно общая проблема по цифровой обработке сигналов, синхронизации сети и ее стабильности. Задача обеспечения временных требований к системным транзакциям: необходимо найти наиболее существенные параметры QoS, позволяющие проводить динамическую перенастройку сети для обеспечения выполнения временных требований к системным транзакциям. Предмет исследования: джиттер телекоммуникационной сети. Целью статьи является разработка метода оперативного расчета значения джиттера телекоммуникационной сети для проведения динамической перенастройки сетевых параметров. Результаты исследования. Проведен анализ влияния нестационарности передачи данных в телекоммуникационной подсистеме, исследуемой компьютерной системы. Исследована роль джиттера на качество передачи информации в телекоммуникационной сети. Проведена классификация джиттера и причин, приводящих к его возникновению. Приведены результаты анализа факторов, улучшающих качество передачи данных в сети за счет оперативного вычисления частотного джиттера. В работе проведены исследования особенностей разрешающей способности когерентных акустооптических спектроанализаторов. Получены аналитические соотношения для выходного сигнала при двух монохроматических радиосигналах на входе, учитывающие эффекты нелинейного взаимодействия выходных сигналов и априорную зависимость местоположения и ширины дифракционного пятна от частоты исследуемого сигнала. Наиболее существенные качественные и количественные характеристики частотного разрешения показаны на примере двух монохроматических сигналов, отличающихся только несущими частотами. Приведенные аналитические соотношения были экспериментально проверены посредством имитационного моделирования системы. Выводы. В результате исследований был предложен способ повышения разрешающей способности акустооптических спектроанализаторов за счет особенностей когерентного взаимодействия сигналов в процессе вычисления частотного джиттера. На его базе разработан метод оперативного расчета значения джиттера телекоммуникационной сети, который позволяет провести динамическую перенастройку сетевых параметров.

Ключевые слова: компьютерная система; телекоммуникационная сеть; джиттер

\section{Бібліографічні описи / Bibliographic descriptions}

Можаєв М. О., Кучук Н. Г., Усатенко М. В. Метод визначення джитера в телекомунікаційній мережі комп'ютерної системи на спеціальній програмній платформі. Сучасний стан наукових досліджень та технологій в промисловості. 2019. № 4 (10). C. 134-140. DOI: https://doi.org/10.30837/2522-9818.2019.10.134.

Mozhaiev, M., Kuchuk, N., Usatenko, M. (2019), "The method of jitter determining in the telecommunication network of a computer system on a special software platform", Innovative Technologies and Scientific Solutions for Industries, No. 4 (10), P. 134140. DOI: https://doi.org/10.30837/2522-9818.2019.10.134. 